\title{
Toll-like Receptors Regulate MIF Expression in Benign Lymphoepithelial Lesion of the Lacrimal Gland
}

\author{
Yao Mawulikplimi Adzavon\#, Pengxiang Zhao" *, Xujuan Zhang, Xin Zhang, Limin Wang, \\ Tarekegn Gebreyesus Abisso, Xuemei Ma
}

College of Life Science and Bio-engineering, Beijing University of Technology, Beijing 100124, P. R. China

\# Contributed equally

* Corresponding author email: zpx@bjut.edu.cn

Received: 19 March 2018 / Accepted: 26 March 2018 / Published: 30 March 2018

\begin{abstract}
Despite a perpetual increase in the prevalence of benign lymphoepithelial lesion, data on the mechanisms governing its pathogenesis are still missing. Thus, we aimed in the present study to evaluate whether TLRs could regulate the expression of the pleiotropic pro-inflammatory and tumor-related cytokine MIF in BLEL. Using gene expression profiling and protein expression analysis methods, we found that TLRs were overexpressed and that their signaling pathways were activated in BLEL. We have also confirmed in tissues biopsies, the overexpression of MIF reported previously in plasma of BLEL specimen. The analysis of the TLR7/8 impact on the expression of MIF in BLEL primary cells showed that when activated, TLR7/8 stimulate mainly BLEL lymphocytes to release MIF but not the fibroblast-like cells. No significant change was observed when MIF expression was investigated at the transcriptional level $24 \mathrm{~h}$ post TLR7/8 activation. Taken together, these data suggest that TLR7 and TLR8 are activated in BLEL and may induce a cell type-dependent regulation of MIF secretion and expression.
\end{abstract}

Keywords: Benign lymphoepithelial lesion; Lacrimal gland; Macrophage migration inhibitory factor; Pathogenesis; Toll-like receptors; Tumor.

\section{Introduction}

Benign lymphoepithelial lesion (BLEL) also known as Mikulicz's disease is a systemic inflammatory IgG4-related disease of lacrimal and salivary glands which affects both men and women, with irreversible consequences such as malignant transformation if left untreated. It's characterized by a chronic bilateral lacrimal and salivary gland enlargement due to infiltration of abundant IgG4 positive plasmacytes into the affected BLEL tissues [1-3]. Since its first description in 1888, the exact etiology of BLEL and the molecular mechanisms underlying its pathogenesis remain unknown. Recently, our team showed that the pro-inflammatory cytokine macrophage migration inhibitory factor (MIF) is overexpressed in the plasma of BLEL patients
[4], however, the causes of this deregulated expression remained unclear.

MIF is a pleiotropic pro-inflammatory cytokine implicated in the pathogenesis of several inflammatory disorders, autoimmune diseases and tumors [5-7]. MIF is synthesized and stored in the cytoplasm of many cells $[8,9]$ and is released in response to various stimuli including Toll-like receptors (TLRs) engagement with their specific ligands [10]. TLRs are involved in several inflammatory diseases and their activation has been shown to trigger the transcription of genes responsible for the synthesis of numerous inflammation cytokines [11-13]. Taken together with the high level of plasmatic MIF reported, the purpose of the present study was to evaluate whether TLRs could be the regulators of MIF expression in BLEL. 


\section{Materials and Methods}

\subsection{Microarray Analysis}

Microarray data of orbital cavernous hemangioma ( $\mathrm{CH}$; control) and BLEL tissue biopsies obtained from gene expression omnibus database (accession number GSE76497) were used to analyze TLRs gene expression between the control and BLEL groups. GeneSpring software version 14.9 (Agilent Technologies) was used for background correction, quantile normalization and to summarized the expression data. A fold change $\geq 2$ and a false discovery rate $($ FDR $)<0.01$ were considered to indicate a statistically significant difference.

\subsection{Western Blot and Immunohistochemistry}

The immunoblotting was performed with targets specific antibodies (Table 1) on total tissue lysates and the immunohistochemistry staining performed with MIF antibodies (sc-271631; Santa Cruz Biotechnology) on paraffinembedded tissue sections from BLEL and $\mathrm{CH}$ specimens as previously described by Adzavon et al. [14].

\subsection{Cell Culture and Stimulation}

After a signed consent was obtained from all patients included in this study, tissues biopsies were collected and primary cells were cultured from fresh tissue biopsies of three (3) BLEL patients. The tissue biopsies were washed with PBS (1X), minced in small pieces, seeded in a Corning ${ }^{\circledR} \mathrm{T} 25$ culture flask and cultured at $37^{\circ} \mathrm{C}$ in presence of $5 \% \quad \mathrm{CO}_{2}$ with DMEM/High glucose (HyClone ${ }^{\circledR}$, ThermoScientific) for adherent cells or RPMI-1640 (gibco $\AA$ by life technology ${ }^{\mathrm{TM}}$ ) for suspension cells. The medium was supplemented with $10 \%$ of Fetal Bovine
Serum (gibco ${ }^{\circledR}$, life technology ${ }^{\mathrm{TM}}$ ) and $1 \%$ of 10,000 Units/ml Penicillin and 10,000 $\mu \mathrm{g} / \mathrm{ml}$ Streptomycin (gibco ${ }^{\circledR}$, life technology ${ }^{\mathrm{TM}}$ ) and was renewed twice a week. The cells were passed when $80-90 \%$ confluence was reached and cells from passage 4 were stimulated with $6 \mu \mathrm{g} / \mathrm{ml}$ of TLR7/8 agonist resiquimod (R848) for $24 \mathrm{~h}$ to mimic TLR7/8 activation in vitro.

\subsection{Enzyme-linked Immunosorbent Assay}

Cell culture supernatants were collected from both R848-stimulated and unstimulated cells and MIF was quantified with RayBio human MIF ELISA kit (RayBiotech.Inc) as we reported previously [14]

\section{$2.5 \quad$ RT-qPCR}

RNA was extracted from BLEL cells and the analysis of MIF and its related receptors genes expression was performed as previously reported [14]. The primers used are listed in the Table 2.

Table 1: List of Antibodies

\begin{tabular}{|l|c|c|l|}
\hline Name & $\begin{array}{c}\text { Host } \\
\text { species }\end{array}$ & $\begin{array}{c}\text { Catalog } \\
\text { Number }\end{array}$ & Provider \\
\hline Beta-Actin (OTI1) & Mouse & TA-09 & ZSGB-BIO \\
\hline MIF (D-2) pouse & sc-271631 & $\begin{array}{l}\text { Santa cruz } \\
\text { biotechnology }\end{array}$ \\
\hline $\begin{array}{l}\text { Anti-NF-kB p65 } \\
\text { antibody }\end{array}$ & Rabbit & ab16502 & Abcam \\
\hline $\begin{array}{l}\text { Phospho-IRF-7 } \\
\text { (Ser471/472) }\end{array}$ & \#5184 & CST \\
\hline $\begin{array}{l}\text { Anti-TLR7 antibody } \\
\text { [EPR2088(2)] }\end{array}$ & Rabbit & ab124928 & Abcam \\
\hline $\begin{array}{l}\text { IRDye® 800CW } \\
\text { Goat anti-mouse }\end{array}$ & Goat & $926-32210$ & LI-COR \\
\hline $\begin{array}{l}\text { IRDye }{ }^{\circledR ~ 800 C W ~} \\
\text { Goat anti-Rabbit }\end{array}$ & Goat & $926-32211$ & LI-COR \\
\hline
\end{tabular}

Table 2: List of primer used for the RT-qPCR

\begin{tabular}{|l|l|l|r|}
\hline $\begin{array}{l}\text { Target } \\
\text { genes }\end{array}$ & Forward (5' to 3') & Revers (5' to 3') & References \\
\hline MIF & CTCTCCGAGCTCACCCAGCAG & CGCGTTCATGTCGTAATAGTT & {$[15]$} \\
\hline CD74 & TGACCAGCGCGACCTTATCT & GAGCAGGTGCATCACATGGT & {$[16]$} \\
\hline CXCR4 & AGGGGATCAGTATATACACTT & TGCCCACAATGCCAGTTAAG & {$[17]$} \\
\hline CXCR2 & AGGCACAGTGAAGACATCGG & CAGCAGGCTCAGCAGGAATA & {$[18]$} \\
\hline CD44 & GTGATGGCACCCGCTATG & ACTGTCTTCGTCTGGGATGG & {$[19]$} \\
\hline TLR7 & AAACTCCTTGGGGCTAGATG & AGGGTGAGGTTCGTGGTGTT & {$[20]$} \\
\hline TLR8 & CAGAGCATCAACCAAAGCAA & GCTGCCGTAGCCTCAAATAC & {$[21]$} \\
\hline GAPDH & ACACCCACTCCTCCACCTTT & TAGCCAAATTCGTTGTCATACC & {$[22]$} \\
\hline
\end{tabular}




\subsection{Statistics}

Quantitative data were analyzed using GraphPad Prism v.5 (GraphPad Software, Inc., La Jolla, CA, USA) and are plotted as the mean \pm standard error of the mean. Unpaired t-test was the statistical test used and p-value less than 0.05 was considered to indicate a statistically significant difference.

\section{Results and Discussion}

\subsection{TLRs Signalization Pathways are Activated in BLEL}

TLRs have crucial functions in host antimicrobial defense, immune cell regulation, and inflammatory response [11-13]. In support of this concept together with the inflammatory response involvement reported in BLEL pathology [2325], we analyzed the expression of TLRs gene in BLEL tissues. Half of the ten TLRs analyzed by microarray were overexpressed compared to the control group $(\mathrm{CH})$ as shown in the Figure $1 \mathrm{~A}$. The results of the mRNA expression were confirmed at proteins level by western blot for TLR7 (Figure 1B). Next, we analyzed the expression of the downstream components of TLRs signalization pathways such as p65/ReLA NF-kB [26, 27] and IRF-7 [28]. This analysis revealed an important expression of the p65/ReLA NF-kB and an enhanced phosphorylation of the Interferon regulatory factor 7 (IRF7), which confirmed that TLRs signaling pathways are activated in BLEL (Figure 1C).
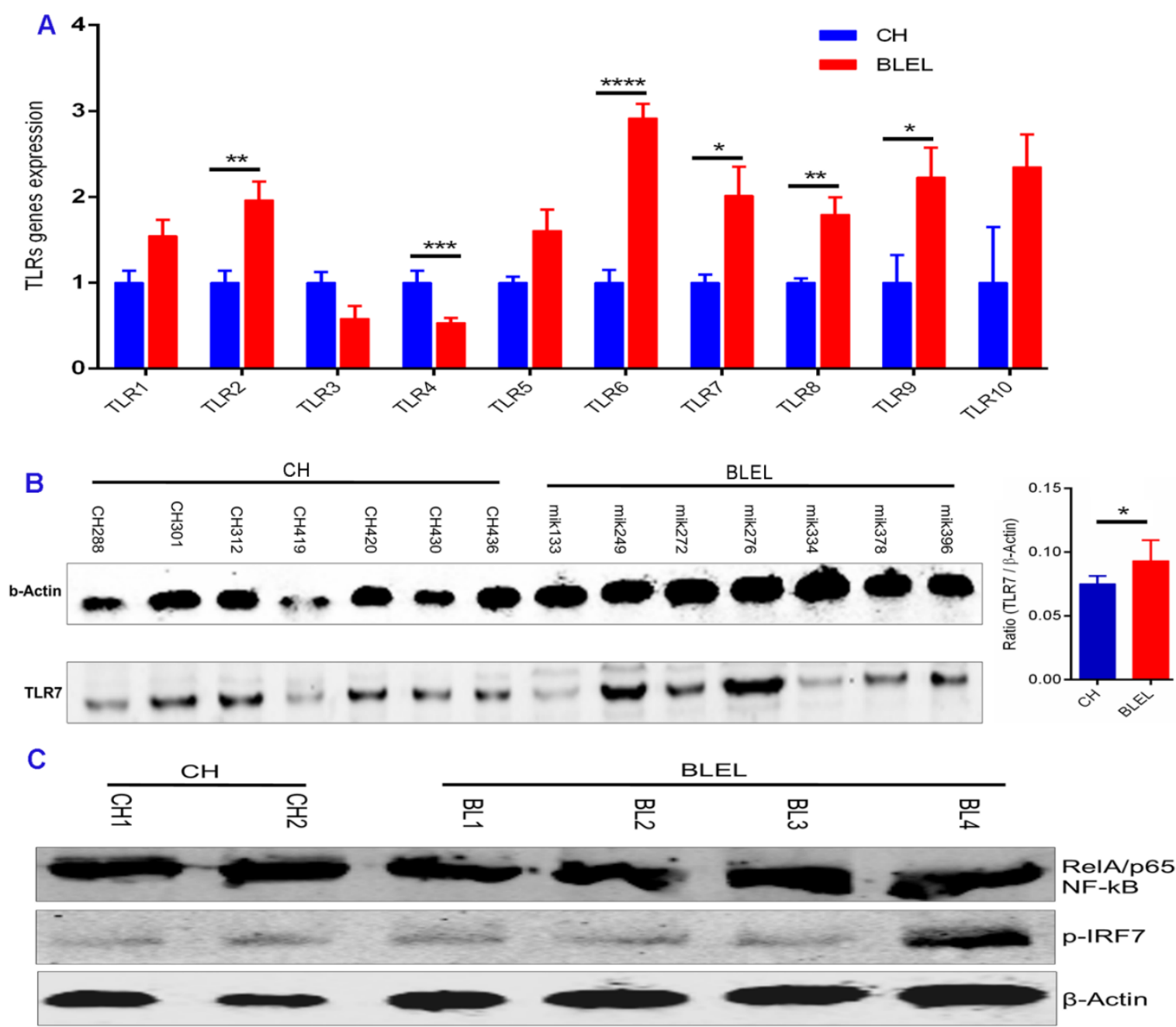

Figure 1: TLRs signaling pathways are activated in BLEL. (A) TLRs mRNA analyzed by microarray. (B) TLRs proteins expression confirmed by western blot. (C) TLR downstream components analyzed by western blot. * $P$ value $<0.05$; ** P-value $<0.01$; *** P-value $<0.001$; no stars for $P$-value $>0.05$ 

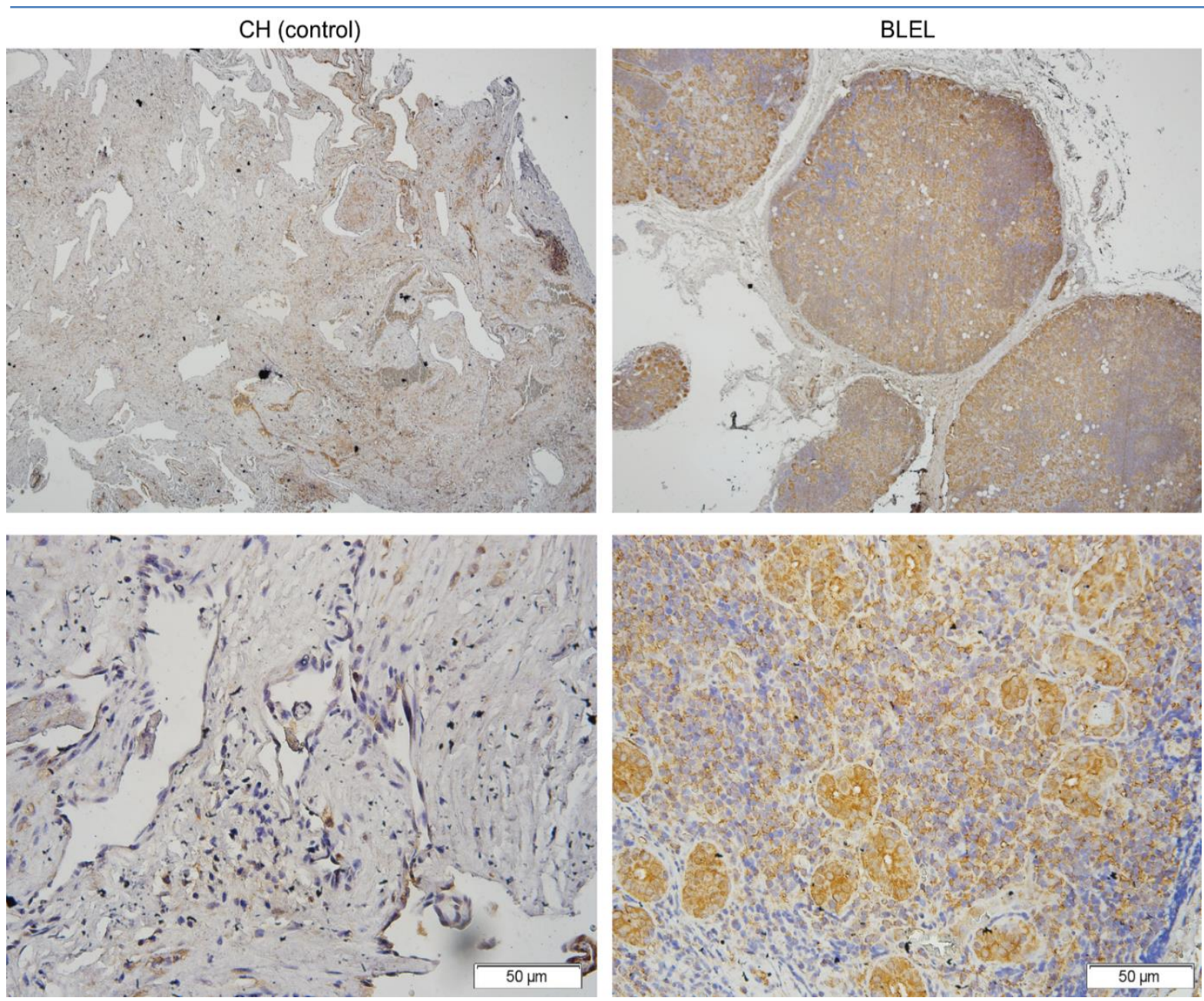

Figure 2: Immunostaining of MIF in BLEL and CH tissues biopsies. The figures presented are representative of staining performed on $10 \mathrm{CH}$ and 10 BLEL specimen tissue biopsies

\subsection{MIF is Overexpressed in BLEL Tissue Biopsies.}

In order to confirm and identify cells that produced and released MIF in BLEL, we performed an immunostaining with MIF antibodies in tissue biopsies. As shown in the Figure 2, MIF is highly expressed in the whole BLEL tissue with the strongest expression noted in infiltrated lymphocytes and epithelial acinar cells.

\subsection{TLRs Differently Regulate MIF Expression in BLEL Primary Cells}

In this investigation, we focused mainly on TLR7/8 pathways given that they were the most enriched among the TLRs pathways in BLEL (Data not showed). Three (3) BLEL primary cells were established for this purpose: two fibroblastlike cells named BLELp1 and BLELp2 and a tissue-derived primary lymphocyte (Figure 3A3C). The expression of TLR $7 / 8$ was confirmed in these primary cells as shown in the Figure 3D. To address whether TLRs influence MIF expression in BLEL, the established BLEL primary cells were stimulated with TLR7/8 agonist R848 $(6 \mu \mathrm{g} / \mathrm{ml})$ for $24 \mathrm{~h}$. Under basal conditions, MIF concentration in the cell culture supernatant varies considerably between the different primary cells. In the absence of TLR7 and TLR8 stimulation, BLEL primary cells secreted a low concentration of MIF. Indeed, the primary fibroblast cells BLELp1 and BLELp2 secreted MIF respectively at a concentration of $4.34 \mathrm{ng} / \mathrm{ml}$ and $1.2 \mathrm{ng} / \mathrm{ml}$ while the MIF released by the tissue-derived lymphocytes was dosed at $2.09 \mathrm{ng} / \mathrm{ml}$. These results are in accordance with the concentration of MIF reported in normal physiological conditions in adult population [29]. 


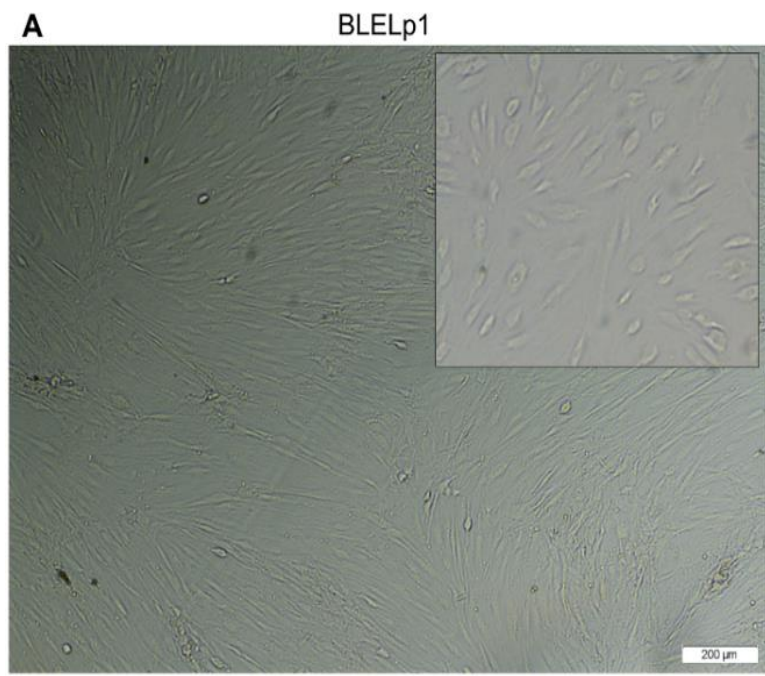

B

BLELP2
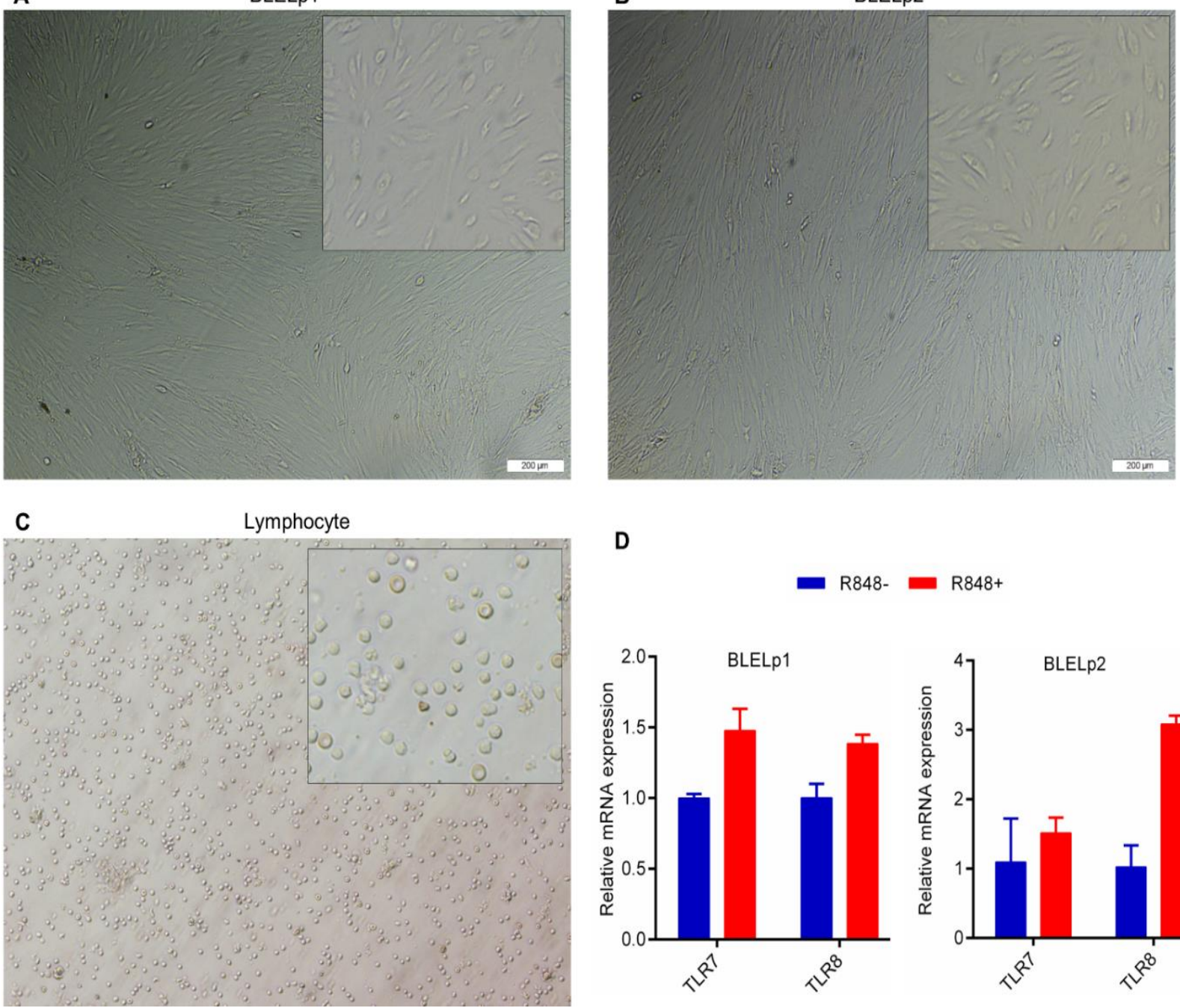

D

- R848- R848+

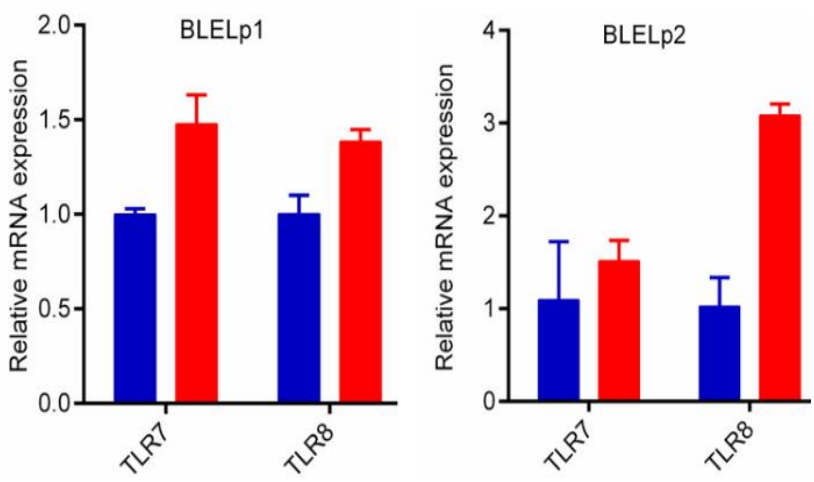

Figure 3: Characteristic of the BLEL primary cells. (A-C) morphological features of the BLEL primary. (D) TLR7/8 mRNA expression analyzed by RT-qPCR before and after treatment with R848. *P-value $<0.05 ; * * P$ value $<0.01$; *** P-value $<0.001$; no stars for $P$-value $>0.05$

Following stimulation with R848, MIF was highly released (13.11 fold increase of MIF in the culture supernatant) by the primary lymphocytes (R848+: $27.53 \mathrm{ng} / \mathrm{ml}$ vs Control: $2.09 \mathrm{ng} / \mathrm{ml}$ ) but not by the primary fibroblast-like cells BLELp1 and BLELp2 (Figure 4A), suggesting that the ability of the fibroblast-like cells to release MIF was abrogated when TLR7 and TLR8 were activated and that in BLEL in which TLR7 and TLR 8 are activated, the lymphocytes would be the main source of the release of MIF in plasma. The fact that TLR 7 and TLR 8 activation induced the release of MIF in the primary lymphocytes but not in the primary fibroblast-like cells is suggestive of a cell type-dependent regulation of MIF secretion in BLEL; an observation reported previously in other cell type $[10,14]$.

At the gene level, TLR7/8 activation did not influence MIF and its receptors mRNA expression (Figure 4B, 4C). This suggests that at least in these two primary cells TLR7 and TLR8 activation do not induce de novo synthesis of MIF. Taken together, these data demonstrate a differentially regulation of MIF expression by TLR7/8 in BLEL and suggested the lymphocytes as one of the main source of the circulating MIF in plasma. 

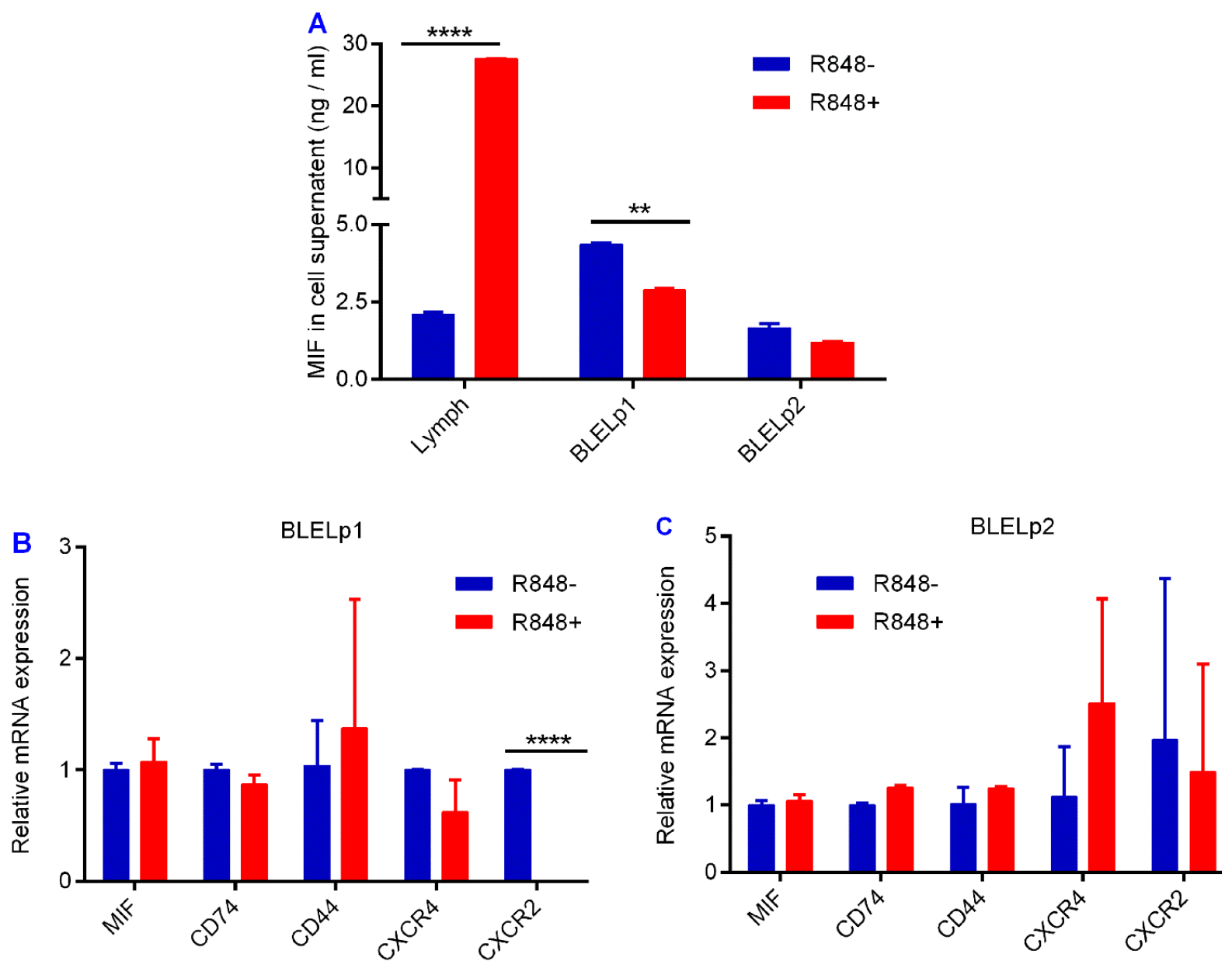

Figure 4: Influence of TLR7/8 activation on the expression of MIF and its receptors in BLEL primary cells. ${ }^{*} P$-value $<0.05$; ** P-value $<0.01$; ** P-value $<0.001$; no stars for $P$-value $>0.05$

MIF biological functions mainly relied on interaction with its receptors $\mathrm{CD} 74, \mathrm{CD} 44$ and CXCR2/4/7 [5, 30-33]. Given that TLR7/8 activation induced the release of MIF in BLEL primary cells, we thought it could also influence the expression of MIF-related receptors; however, following $24 \mathrm{~h}$ of exposure to TLR7/8 agonist R848, no significant change was observed (Figure 4B \& 4C).

\section{Conclusions}

In the present study, we provide evidence that TLR7 and TLR8 pathways are activated and regulated MIF proteins expression in BLEL, however, this influence may differ from one cell type to another. In addition, given the proinflammatory properties of MIF, it could be conceivable that TLRs play key roles in the regulation of the inflammatory response in BLEL.

\section{Declaration}

\subsection{Funding Source}

This work was supported by the National Natural Science Foundation of China (81602408) and Ri Xin Ren Cai project of Beijing University of Technology (2018)

\subsection{Study Limitations}

None

\subsection{Ethical Approval}

This study has been approved by the Local Ethics Committee of Beijing Tongren Hospital, Capital Medical University (CHINA).

\subsection{Informed Consent}

A signed consent was obtained from each patient prior to tissues collection. 


\subsection{Competing Interests}

The authors have declared that no conflict of interest exists

\section{How to Cite this Article:}

M. Adzavon, "Toll-like Receptors Regulate MIF Expression in Benign Lymphoepithelial Lesion of the Lacrimal Gland", International Annals of Science, vol. 4, no. 1, pp. 27-34, 2018. doi: 10.21467/ias.4.1.27-34

\section{References}

[1] M. Moriyama, A. Tanaka, T. Maehara, Y. Ohyama, M. Shimizu, H. Nakashima, J. N. Hayashida, S. Shinozaki, Y. Kubo, S. Furukawa, T. Kikuta, and S. Nakamura, "Clinical characteristics of Mikulicz's disease as an IgG4-related disease," Clin Oral Investig, vol. 17, no. 9, pp. 1995-2002, Dec, 2013.

[2] M. Yamamoto, H. Takahashi, M. Ohara, C. Suzuki, Y. Naishiro, H. Yamamoto, Y. Shinomura, and K. Imai, "A new conceptualization for Mikulicz's disease as an IgG4-related plasmacytic disease," Mod Rheumatol, vol. 16, no. 6, pp. 335-40, 2006.

[3] M. Yamamoto, H. Takahashi, S. Sugai, and K. Imai, "Clinical and pathological characteristics of Mikulicz's disease (IgG4-related plasmacytic exocrinopathy)," Autoimmunity Reviews, vol. 4, no. 4, pp. 195-200, 4//, 2005.

[4] Q. J. Li, P. X. Zhao, X. J. Zhang, Y. Yi, D. Y. Cheng, J. M. Ma, and X. M. Ma, "Association of the macrophage migration inhibitory factor promoter polymorphisms with benign lymphoepithelial lesion of lacrimal gland," Int J Ophthalmol, vol. 10, no. 8, pp. 1229-1232, 2017.

[5] T. Lang, A. Foote, J. P. Lee, E. F. Morand, and J. Harris, "MIF: Implications in the Pathoetiology of Systemic Lupus Erythematosus," Front Immunol, vol. 6 , pp. 577, 2015.

[6] C. C. Nobre, J. M. de Araujo, T. A. Fernandes, R. N. Cobucci, D. C. Lanza, V. S. Andrade, and J. V. Fernandes, "Macrophage Migration Inhibitory Factor (MIF): Biological Activities and Relation with Cancer," Pathol Oncol Res, Oct 23, 2016.

[7] R. Fukaya, S. Ohta, T. Yaguchi, Y. Matsuzaki, E. Sugihara, H. Okano, H. Saya, Y. Kawakami, T. Kawase, K. Yoshida, and M. Toda, "MIF Maintains the Tumorigenic Capacity of Brain Tumor-Initiating Cells by Directly Inhibiting p53," Cancer Res, vol. 76, no. 9, pp. 2813-23, May 1, 2016

[8] J. A. Baugh, and R. Bucala, "Macrophage migration inhibitory factor," Crit Care Med, vol. 30, no. 1 Supp, pp. S27-s35, Jan, 2002.

[9] H. Lue, R. Kleemann, T. Calandra, T. Roger, and J. Bernhagen, "Macrophage migration inhibitory factor (MIF): mechanisms of action and role in disease," Microbes Infect, vol. 4, no. 4, pp. 449-60, Apr, 2002.

[10] C. Popa, A. W. van Lieshout, M. F. Roelofs, A. Geurts-Moespot, P. L. van Riel, T. Calandra, F. C. Sweep, and T. R. Radstake, "MIF production by dendritic cells is differentially regulated by Toll-like receptors and increased during rheumatoid arthritis," Cytokine, vol. 36, no. 1-2, pp. 51-6, Oct, 2006.
S. Akira, and K. Takeda, "Toll-like receptor signalling," Nat Rev Immunol, vol. 4, no. 7, pp. 499511, Jul, 2004.

N. J. Gay, M. F. Symmons, M. Gangloff, and C. E. Bryant, "Assembly and localization of Toll-like receptor signalling complexes," Nat Rev Immunol, vol. 14, no. 8, pp. 546-58, Aug, 2014.

[13] O. Takeuchi, and S. Akira, "Pattern Recognition Receptors and Inflammation," Cell, vol. 140, no. 6, pp. 805-820, 3/19/, 2010.

[14] Y. M. Adzavon, P. Zhao, B. Lv, M. Liu, X. Zhang, F. Xie, L. Yang, L. Shang, M. Zhang, Q. Li, and X. Ma, "TLR7 and TLR8 agonist resiquimod (R848) differently regulates MIF expression in cells and organs," Cytokine, vol. 97, pp. 156-166, Sep, 2017.

[15] S. Wada, S. Fujimoto, Y. Mizue, and J. Nishihira, "Macrophage migration inhibitory factor in the human ovary: presence in the follicular fluids and production by granulosa cells," Biochem Mol Biol Int, vol. 41, no. 4, pp. 805-14, Apr, 1997.

[16] J. D. Burton, S. Ely, P. K. Reddy, R. Stein, D. V. Gold, T. M. Cardillo, and D. M. Goldenberg, "CD74 is expressed by multiple myeloma and is a promising target for therapy," Clin Cancer Res, vol. 10, no. 19, pp. 6606-11, Oct 01, 2004.

[17] J. P. Salim, N. P. Goette, P. R. Lev, C. D. Chazarreta, P. G. Heller, C. Alvarez, F. C. Molinas, and R. F. Marta, "Dysregulation of stromal derived factor $1 / \mathrm{CXCR} 4$ axis in the megakaryocytic lineage in essential thrombocythemia," Br J Haematol, vol. 144, no. 1, pp. 69-77, Jan, 2009.

[18] Z. Liu, L. Yang, J. Xu, X. Zhang, and B. Wang, "Enhanced expression and clinical significance of chemokine receptor CXCR2 in hepatocellular carcinoma," J Surg Res, vol. 166, no. 2, pp. 241-6, Apr, 2011

[19] J. Su, X. Chen, Y. Huang, W. Li, J. Li, K. Cao, G. Cao, L. Zhang, F. Li, A. I. Roberts, H. Kang, P. Yu, G. Ren, W. Ji, Y. Wang, and Y. Shi, "Phylogenetic distinction of iNOS and IDO function in mesenchymal stem cellmediated immunosuppression in mammalian species," Cell Death Differ, vol. 21, no. 3, pp. 388-396, 03//print, 2014.

[20] R. M. Valente, E. Ehlers, D. Xu, H. Ahmad, A. Steadman, L. Blasnitz, Y. Zhou, L. Kastanek, B. Meng, and L. Zhang, "Toll-like receptor 7 stimulates the expression of Epstein-Barr virus latent membrane protein 1," PLoS One, vol. 7, no. 8, pp. e43317, 2012.

[21] Y. Zhang, H. Yang, P. A. Barnie, P. Yang, Z. Su, J. Chen, Z. Jiao, L. Lu, S. Wang, and H. Xu, "The expression of Toll-like receptor 8 and its relationship with VEGF and Bcl-2 in cervical cancer," Int J Med Sci, vol. 11, no. 6, pp. 608-13, 2014.

[22] K. C. Lai, S. C. Hsu, J. S. Yang, C. C. Yu, J. C. Lein, and J. G. Chung, "Diallyl trisulfide inhibits migration, invasion and angiogenesis of human colon cancer HT29 cells and umbilical vein endothelial cells, and suppresses murine xenograft tumour growth," J Cell Mol Med, vol. 19, no. 2, pp. 474-84, Feb, 2015.

[23] A. Tanaka, M. Moriyama, H. Nakashima, K. Miyake, J. N. Hayashida, T. Maehara, S. Shinozaki, Y. Kubo, and S. Nakamura, "Th2 and regulatory immune reactions contribute to $\mathrm{IgG} 4$ production and the initiation of Mikulicz disease," Arthritis Rheum, vol. 64, no. 1, pp. 254-63, Jan, 2012. 
[24] T. Maehara, M. Moriyama, H. Nakashima, K. Miyake, J. N. Hayashida, A. Tanaka, S. Shinozaki, Y. Kubo, and S. Nakamura, "Interleukin-21 contributes to germinal centre formation and immunoglobulin G4 production in IgG4-related dacryoadenitis and sialoadenitis, so-called Mikulicz's disease," Ann Rheum Dis, vol. 71, no. 12, pp. 2011-19, Dec, 2012.

[25] E. Kudo-Tanaka, S. Nakatsuka, T. Hirano, M. Kawai, Y. Katada, M. Matsushita, S. Ohshima, M. Ishii, K. Miyatake, T. Tanaka, and Y. Saeki, "A case of Mikulicz's disease with Th2-biased cytokine profile: possible feature discriminable from Sjogren's syndrome," Mod Rheumatol, vol. 19, no. 6, pp. 691-5, 2009.

[26] G. Zhang, and S. Ghosh, "Toll-like receptor-mediated NF-kappaB activation: a phylogenetically conserved paradigm in innate immunity," J Clin Invest, vol. 107, no. 1, pp. 13-9, Jan, 2001.

[27] G. Bonizzi, and M. Karin, "The two NF-\&\#x3ba;B activation pathways and their role in innate and adaptive immunity," Trends in Immunology, vol. 25, no. 6, pp. 280-288.

[28] T. Kawasaki, and T. Kawai, "Toll-like receptor signaling pathways," Frontiers in immunology, vol. 5, 2014.

[29] T. Roger, L. J. Schlapbach, A. Schneider, M. Weier, S. Wellmann, P. Marquis, D. Vermijlen, F. C. G. J. Sweep, L. Leng, R. Bucala, T. Calandra, and E. Giannoni, "Plasma Levels of Macrophage Migration Inhibitory Factor and d-Dopachrome Tautomerase Show a Highly Specific Profile in Early Life," Frontiers in Immunology, vol. 8:26, 2017.

[30] A. Zernecke, J. Bernhagen, and C. Weber, "Macrophage migration inhibitory factor in cardiovascular disease," Circulation, vol. 117, no. 12, pp. 1594-602, Mar 25, 2008.

[31] J. Bernhagen, R. Krohn, H. Lue, J. L. Gregory, A. Zernecke, R. R. Koenen, M. Dewor, I. Georgiev, A. Schober, L. Leng, T. Kooistra, G. Fingerle-Rowson, P. Ghezzi, R. Kleemann, S. R. McColl, R. Bucala, M. J. Hickey, and C. Weber, "MIF is a noncognate ligand of CXC chemokine receptors in inflammatory and atherogenic cell recruitment," Nat Med, vol. 13, no. 5, pp. 587-96, May, 2007.

[32] S. Alampour-Rajabi, O. El Bounkari, A. Rot, G. Muller-Newen, F. Bachelerie, M. Gawaz, C. Weber, A. Schober, and J. Bernhagen, "MIF interacts with CXCR7 to promote receptor internalization, ERK1/2 and ZAP-70 signaling, and lymphocyte chemotaxis," Faseb j, vol. 29, no. 11, pp. 4497-511, Nov, 2015.

[33] C. Klasen, K. Ohl, M. Sternkopf, I. Shachar, C. Schmitz, N. Heussen, E. Hobeika, E. Levit-Zerdoun, K. Tenbrock, M. Reth, J. Bernhagen, and O. El Bounkari, "MIF promotes B cell chemotaxis through the receptors CXCR4 and CD74 and ZAP-70 signaling," J Immunol, vol. 192, no. 11, pp. 5273-84, Jun 1, 2014.
Publish your research article in AIJR journals-

$\checkmark$ Online Submission and Tracking

$\checkmark$ Peer-Reviewed

$\checkmark$ Rapid decision

$\checkmark \quad$ Immediate Publication after acceptance

$\checkmark \quad$ Articles freely available online

$\checkmark \quad$ Retain full copyright of your article.

Submit your article at journals.aijr.in

\section{Publish your books with AIJR publisher-}

$\checkmark \quad$ Publish with ISBN and DOI.

$\checkmark$ Publish Thesis/Dissertation as Monograph.

$\checkmark \quad$ Publish Book Monograph.

$\checkmark \quad$ Publish Edited Volume/ Book.

$\checkmark$ Publish Conference Proceedings

$\checkmark \quad$ Retain full copyright of your books.

Submit your manuscript at books.aijr.org 